\title{
MENINGKATKAN PRESTASI BELAJAR PELAJARAN IPS MELALUI GABUNGAN METODE CERAMAH DENGAN METODE BELAJAR AKTIF MODEL PENGAJARAN AUTENTIK
}

\author{
Suryanto \\ Guru SDN 07 Sungai Mata
}

\begin{abstract}
Abstrak:Dalam mengajar, guru jarang sekali menggunakan satu metode, karena mereka menyadari bahwa semua metode ada kebaikan dan kelemahannya. Penggunaan satu metode lebih cenderung menghasilkan kegiatan belajar mengajar yang membosankan bagi anak didik. Jalan pengajaran pun tampak kaku. Anak didik terlihat kurang bergairah belajar. Kejenuhan dan kemalasan menyelimuti kegiatan belajar anak didik. Kondisi seperti ini sangat tidak menguntungkan bagi guru dan anak didik. Penelitian ini menggunakan penelitian tindakan (action research) sebanyak tiga siklus. Setiap siklus terdiri dari empat tahap yaitu: rancangan, kegiatan, pengamatan, refleksi, dan refisi. Sasaran penelitian ini adalah siswa Kelas IV SDN 07 Sei. Mata-mata Kabupaten Kayong Utara semester ganjil tahun pelajaran 2016/2017. Data yang diperoleh berupa hasil tes formatif, lembar observasi kegiatan belajar mengajar. Dari hasil analisis didapatkan bahwa prestasi belajar siswa mengalami peningkatan dari siklus I sampai siklus III yaitu, siklus I (67,65\%), siklus II (79,41\%), siklus III (91,17\%). Simpulan dari penelitian ini adalah gabungan metode ceramah dengan metode pengajaran autentik dapat berpengaruh positif terhadap motivasi belajar Siswa Kelas IV SDN 07 Sei. Mata-mata Kabupaten Kayong Utara semester ganjil tahun pelajaran 2016/2017 serta model pembelajaran ini dapat digunakan sebagai salah satu alternatif pembelajaran Ilmu Pengetahuan Sosial.
\end{abstract}

Kata Kunci: Pengetahuan Sosial, Metode Ceramah, Pengajaran Autentik

\section{PENDAHULUAN}

Dalam menggunakan metode terkadang guru harus menyesuaikan dengan kondisi dan suasana kelas. Jumlah anak mempengaruhi penggunaan metode. Tujuan instruksional adalah pedoman yang mutlak dalam pemilihan metode. Dalam perumusan tujuan, guru perlu merumuskannya dengan jelas dan dapat diukur. Dengan begitu mudahlah bagi guru menentukan metode bagaimana yang dipilih guna menunjang pencapaian tujuan yang telah dirumuskan tersebut.

Dalam mengajar, guru jarang sekali menggunakan satu metode, karena mereka menyadari bahwa semua metode ada kebaikan dan kelemahannya. Penggunaan satu metode lebih cenderung menghasilkan kegiatan belajar mengajar yang membosankan bagi anak didik. Jalan pengajaran pun tampak kaku. Anak didik terlihat kurang bergairah belajar. Kejenuhan dan kemalasan menyelimuti kegiatan belajar anak didik. Kondisi seperti ini sangat tidak menguntungkan bagi guru dan anak didik.

Sementara itu ada pemikiran bahwa anak akan belajar lebih baik jika lingkungan diciptakan secara alamiah. Belajar akan lebih bermakna jika anak "mengalami" sendiri apa yang dipelajarinya, bukan 'mengetahui'-nya. Pembelajaran yang berorientasi target penguasaan materi terbukti berhasil dalam kompetisi 'mengingat' jangka pendek, tetapi gagal dalam membekali anak memecahkan 
persoalan dalam kehidupan jangkan panjang. Dan, itulah yang terjadi di kelas-kelas sekolah kita. Pendekatan kontekstual (contextual teaching learning/CTL) adalah suatu pendekatan pengajaran yang dari karakteristiknya memenuhi harapan itu. Sekarang ini pengajaran kontekstual menjadi tumpuan harapan para ahli pendidikan dan pengajaran dalam upaya menghidupkan kelas secara maksimal. Kelas yang hidup diharapkan dapat mengimbangi perubahan yang terjadi di luar sekolah yang sedemikian cepat.

Mengajar bukan semata persoalan menceritakan. Belajar bukanlah konsekkuensi otomatis dari perenungan informasi ke dalam benak siswa. Belajar memerlukan keterlibatan mental dan kerja siswa sendiri. Penjelasan dan pemeragaan semata tidak akan membuahkan hasil belajar yang langgeng. Yang bisa membuahkan hasil belajar yang langgeng hanyalah kegiatan belajar aktif.

Apa yang menjadikan belajar aktif? Agar belajar menjadi aktif siswa harus mengerjakan banyak sekali tugas. Mereka harus menggunakan otak, mengkaji gagasan, memecahkan masalah, dan menerapkan apa yang mereka pelajari. Belajar aktif harus gesit, menyenangkan, bersemangat dan penuh gairah. Siswa bahkan sering meninggalkan tempat duduk mereka, bergerak leluasa dan berfikir keras (moving about dan thinking aloud).

Setiap akan mengajar, guru perlu membuat persiapan mengajar dalam rangka melaksanakan sebagian dari rencana bulanan dan rencana tahunan. Dalam persiapan itu sudah terkandung tentang, tujuan mengajar, pokok yang akan diajarkan, metode mengajar, bahan pelajaran, alat peraga dan teknik evaluasi yang digunakan. Karena itu setiap guru harus memahami benar tentang tujuan mengajar, secara khusus memilih dan menentukan metode mengajar sesuai dengan tujuan yang hendak dicapai, cara memilih, menentukan dan menggunakan alat peraga, cara membuat tes dan menggunakannya, dan pengetahuan tentang alat-alat evaluasi.

Sementara itu teknologi pembelajaran adalah salah satu dari aspek tersebut yang cenderung diabaikan oleh beberapa pelaku pendidikan, terutama bagi mereka yang menganggap bahwa sumber daya manusia pendidikan, sarana dan prasarana pendidikan lah yang terpenting. Padahal kalau dikaji lebih lanjut, setiap pembelajaran pada semua tingkat pendidikan baik formal maupun non formal apalagi tingkat Sekolah Dasar, haruslah berpusat pada kebutuhan perkembangan anak sebagai calon individu yang unik, sebagai makhluk sosial, dan sebagai calon manusia seutuhnya.

Hal tersebut dapat dicapai apabila dalam aktivitas belajar mengajar, guru senantiasa memanfaatkan teknologi pembelajaran yang mengacu pada pembelajaran struktural dalam penyampaian materi dan mudah diserap peserta didik atau siswa berbeda.

Khususnya dalam pembelajaran Ilmu Pengetahuan Sosial, agar siswa dapat memahami materi yang disampaikan guru dengan baik, maka proses pembelajaran kontektual, guru akan memulai membuka pelajaran dengan menyampaikan kata kunci, tujuan yang ingin dicapai, baru memaparkan isi dan diakhiri dengan memberikan soal-soal kepada siswa.

Dengan menyadari gejala-gejala atau kenyataan tersebut diatas, maka dalam penelitian ini penulis mengambil judul "Meningkatkan Prestasi Belajar Mata Pelajaran IPS Melalui Gabungan Metode Ceramah Dengan Metode Belajar Aktif Model Pengajaran Autentik Pada Siswa Kelas IV SDN 07 Sei. Mata-mata."

Bertitik tolak dari latar belakang diatas maka penulis merumuskan permasalahnnya sebagai berikut: (a)Bagaimanakah peningkatan prestasi belajar Ilmu Pengetahuan Sosial dengan diterapkannya gabungan metode ceramah dengan metode belajar aktif model pengajaran autentik pada siswa . (b) Bagaimanakah pengaruh gabungan metode ceramah dengan metode belajar aktif model pengajaran autentik terhadap motivasi belajar Ilmu Pengetahuan Sosial pada siswa .

Sesuai dengan permasalahan di atas, penelitian ini bertujuan untuk: (a) Ingin mengetahui peningkatan prestasi belajar Ilmu Pengetahuan Sosial setelah diterapkannya gabungan metode ceramah dengan metode belajar aktif model pengajaran autentik. (b) Ingin mengetahui pengaruh motivasi belajar Ilmu Pengetahuan Sosial setelah diterapkan 
gabungan metode ceramah dengan metode belajar aktif model pengajaran autentik.

Adapun maksud penulis mengadakan penelitian ini diharapkan dapat berguna sebagai: (a). Menambah pengetahuan dan wawasan penulis tentang peranan guru Ilmu Pengetahuan Sosial dalam meningkatkan pemahaman siswa belajar Ilmu Pengetahuan Sosial. (b). Sumbangan pemikiran bagi guru Ilmu Pengetahuan Sosial dalam mengajar dan meningkatkan pemahaman siswa belajar Ilmu Pengetahuan Sosial di Kelas IV SDN 07 Sei. Mata-mata Kabupaten Kayong Utara semester ganjil tahun pelajaran 2016/2017.

Penelitian ini dilaksanakan pada siswa Kelas IV SDN 07 Sei. Mata-mata Kabupaten Kayong Utara pada bulan September semester ganjil tahun pelajaran 2016/2017, dengan pokok bahasan jenis kegiatan ekonomi

Pembelajaran adalah proses, cara, menjadikan orang atau makhluk hidup belajar. Sedangkan belajar adalah berusaha memperoleh kepandaian atau ilmu, berubah tingkah laku atau tanggapan yang disebabkan oleh pengalaman. (KBBI, 1996: 14).

Sependapat dengan pernyataan tersebut Sutomo (1993: 68) mengemukakan bahwa pembelajaran adalah proses pengelolaan lingkungan seseorang yang dengan sengaja dilakukan sehingga memungkinkan dia belajar untuk melakukan atau mempertunjukkan tingkah laku tertentu pula. Sedangkan belajar adalah suatu proses yang menyebabkan perubahan tingkah laku yang bukan disebabkan oleh proses pertumbuhan yang bersifat fisik, tetapi perubahan dalam kebiasaan, kecakapan, bertambah, berkembang daya pikir, sikap dan lain-lain. (Soetomo, 1993: 120).

Jadi pembelajaran adalah proses yang disengaja yang menyebabkan siswa belajar pada suatu lingkungan belajar untuk melakukan kegiatan pada situasi tertentu.

Metode ceramah terkadang disebut sebagai metode kuliah, dapat juga disebut metode deskripsi. Sesuai dengan namanya, berceramah dipergunakan sebagai metode mengajar.

Sedangkan menurut Hasibuan dan Mudjiono (1981), metode ceramah adalah cara penyampain bahan pelajaran dengan komunikasi lisan.
Jadi metode ceramah adalah metode belajar yang digunakan untuk menyampaikan pelajaran yang sesuai dengan rumusan metode belajar mengajar. Penggunaan metode ceramah secara terus menerus dalam proses belajar kurang tepat karena dapat menimbulkan kejenuhan pada siswa.

Gambaran pengajaran dengan pendekatan ceramah adalah sebagai berikut; guru mendominasi kegiatan belajar mengajar, definisi dan rumus diberikannya, contohcontoh soal diberikan dan dekerjakan sendiri oleh guru, langkah-langkah guru diikuti dengan teliti oleh siswa.

Kelemahan Metode Ceramah : (1) Pelajaran berjalan membosankan karena siswa tidak diberi kesempatan untuk menemukan sendiri konsep yang diajarkan. (2) Siswa menjadi pasif hanya aktif membuat catatan saja. (3) Kepadatan konsep-konsep yang diajarkan dapat berakibat siswa tidak mampu menguasai bahan yang diajarkan. (4) Pengetahuan yang diperoleh melalui ceramah lebih cepat terlupakan.

Ceramah menyebabkan sistem belajar siswa menjadi "belajar menghafal" dan tidak mengacu pada timbulnya pengertian.

Walaupun dalam metode ini, seluruh kegiatan didominasi oleh guru, siswa juga berperan dalam metode ceramah yaitu; (1) Mengadakan interpretasi terhadap keterangan guru. (2) Mendengarkan dan memperhatikan dengan baik keterangan guru. (3) Mengadakan asimilasi, apabila tidak ada interpertasi yang benar. (4) Mengadakan pencatatan yang diperlukan

Dalam metode ceramah, peran utama adalah guru. Karena pelaksanaan metode ceramah merupakan komunikasi satu arah, dalam arti guru mendominasi seluruh kegiatan belajra mengajar. Berhasil tidaknya metode ceramah tergantung sebagian besar pada guru. Berceramah merupakan salah satu dari metode pengajaran yang paling lama digunakan, namun apakah metode semacam ini memiliki tempat dalam lingkungan belajar aktif? Karena terlalu sering digunakan, metode ceramah tidak akan mengantarkan pada pembelajaran, namun ada kalanya cara ini bisa efektif. Agar bisa efektif, guru harus terlebih dahulu membangkitkan minat, memaksimalkan pemahaman dan pengingatan, melibatkan siswa selama 
penceramahan, dan menekankan kembali apa yang telah disajikan. Berikut adalah sejumlah pilihan untuk melakukan hal itu.

Ada sejumlah alasan mengapa sebagian besar orang cenderung lupa tentang apa yang mereka dengar. Salah satu alasan yang paling menarik ada kaitannya dengan tingkat kecepatan bicara guru dan tingkat kecepatan pendengaran siswa.

Pada umumnya guru berbicara dengan kecepatan 100 hingga 200 kata permenit. Tetapi beberapa kata-kata yang dapat ditangkap siswa dalam per menitnya, Ini tentunya juga bergantung pada cara mereka mendengarkan. Jika siswa benar-benar berkonsentrasi, akan akan dapat mendengarkan dengan penuh perhatian terhadap 50 sampai 100 kata per menit, atau setengah dari apa yang dikatakan guru. Itu karena siswa juga berpikir banyak selama mereka mendengarkan. Akan sulit menyimak guru yang bicaranya cepat. Besar kemungkinan, siswa tidak bisa konsentrasi sekalipun materinya menarik, berskonsentrasi dalam waktu yang lama memang bukan perkara mudah. Penelitian menunjukkan bahwa siswa mampu mendengarkan (tanpa memikirkan) denga kecepatan 400 hingga 500 kata per menit. Ketika mendengarkan dalam waktu berkepanjangan terhadap seorang guru yang berbicara lambat, siswa cenderung menjadi jenuh, dan pikiran mereka mengembara entah ke mana.

Bahkan, sebuah penelitian menunjukkan bahwa dalam suatu perkualiahan bergaya ceramah, mahasiswa kurang menaruh perhatian selama 40\% dari seluruh waktu kuliah (Pollio, 1984). Mahasiswa dapat mengingat 70 persen dalam sepuluh menit pertama kuliah, sedangkan dalam sepuluh menit terakhir, mereka hany dapat mengingat 20\% materi kuliah mereka (McKeachie, 1986). Tidak heran bila masisiwa dalam kuliah psikologi yang disampaikan dengan gaya ceramah hanya mengetahui $8 \%$ lebih banyak dari kelompok pembanding yang sama sekali belum pernah mengikuti kuliah itu (Richard, dkk., 1989). Dua figur terkenal dalam gerakan kooperatif, David dan Roger Jonson, bersama Karl Smith, mengemukakan beberapa persoalan berkenaan dengan perkuliahan yang berkepanjangan (Johnson, Johnson \& Smith, 1991).
(1) Perhatian masasiswa menurun seiring berlalunya waktu, (2) Cara kuliah macam ini hanya menarik bagi peserta didik auditori, (3) Cara ini cenderung mengakibatkan kurangnya proses belajar mengajar tentang informasi faktual. (4) Cara ini mengasumsikan bahwa mahasiswa memerlukan informasi yang sama dengan langkah penyampaian yang sama dengan langkah penyampaian yang sama pula. (5) Mahasiswa cenderung tidak menyukainya.

Dengan menambahkan media visual pada pemberian pelajaran, ingatan akan meningkat dari 14 hingga 38 persen (Pike, 1989). Penelitian juga menunjukkan adanya peningkatan hingga 200 persen ketika digunakan media visual dalam mengajarkan kosa kata. Tidak hanya itu, waktu yang diperlukan untuk menyajikan sebuah konsep dapat berkurang hingga 40 persen ketika media visual digunakan untuk mendukung presentasi lisan. Sebuah gambar barangkali tidak memiliki ribuan kata, namun ia tiga kali lebih efektif ketimbang kata-kata saja.

Ketika pengajaran memiliki dimensi auditori dan visual, pesan yang diberikan akan menjadi lebih kuat berkat kedua sistem penyampaian itu. Juga, sebagian siswa, seperti akan kita bahas nanti. Lebih menyukai satu cara penyampaian ketimbang cara yang lain. Dengan menggunakan keduanya, kita memiliki peluang yang lebih besar untuk memenuhi kebutuhan dari beberapa tipe siswa. Namum demikian belajar tidaklah cukup hanya dengan mendengarkan atau melihat sesuatu.

Pengajaran autentik yaitu pendekatan pengajaran yang memperkenankan siswa untuk mempelajari konteks bermakna. Siswa mengembangkan keterampilan berpikir dan pemecahan masalah yang penting dalam konteks kehidupan nyata. Siswa sering kali mengalami kesulitan dalam menerapkan keterampilan yang telah mereka dapatkan di sekolah ke dalam kehidupan nyata sehari-hari karena keterampilan-keterampilan itu lebih diajarkan dalam konteks (situasi yang ada hubungannya dengan) sekolah ketimbang konteks kehidupan nyata.

Tugas-tugas sekolah sering lemah dalam konteks (tidak autentik), sehingga tidak bermakna bagi kebanyakan siswa karena siswa tidak dapat menghubungkan tugas-tugas ini 
denga apa yang telah mereka ketahui. Guru dapat membantu siswa untuk belajar memecahkan masalah dengan memberi tugastugas yang memiliki konteks kehidupan nyata dan kaya dengan kandungan akademik serta keterampilan yang terdapat dalam konteks kehidupan nyata. Untuk memecahkan masalah - masalah tersebut, siswa harus mengidentifikasi masalah, mengidentifikasi kemungkinan pemecahannya, memilih suatu pemecahan, melaksanakan pemecahana atas masalah mereka. Dengan begitu, siswa akan belajar menerapkan keterampilan akademik seperti pengumpulan informasi, menghitung, menulis dan berbicara di dalam konteks kehidupan nyata.

\section{METODOLOGI}

Penelitian ini bertempat di Kelas IV SDN 07 Sei. Mata-mata Kabupaten Kayong Utara semester ganjil tahun pelajaran 2016/2017. Dengan waktu penelitian pada bulan september semester ganjil tahun pelajaran 2016/2017. Subyek penelitian adalah siswa-siswi Kelas IV SDN 07 Sei. Mata-mata Kecamatan Simpang Hilir Kabupaten Kayong Utara pada pokok bahasan jenis kegiatan ekonomi.

Penelitian ini menggunakan Penelitian Tindakan Kelas (PTK). Menurut Tim Pelatih Proyek PGSM, PTK adalah suatu bentuk kajian yang bersifat reflektif oleh pelaku tindakan yang dilakukan untuk meningkatkan kemantapan rasional dari tindakan mereka dalam melaksanakan tugas, memperdalam pemahaman terhadap tindakan-tindakan yang dilakukan itu, serta memperbaiki kondisi dimana praktek pembelajaran tersebut dilakukan (dalam Mukhlis, 2000: 3).

Sedangkah menurut Mukhlis (2000: 5) PTK adalah suatu bentuk kajian yang bersifat sistematis reflektif oleh pelaku tindakan untuk memperbaiki kondisi pembelajaran yang dilakukan. Data-data yang diperlukan dalam penelitian ini diperoleh melalui observasi pengolahan belajar aktif, observasi aktivitas siswa dan guru, dan tes formatif.

Untuk mengetahui keefektivan suatu metode dalam kegiatan pembelajaran perlu diadakan analisa data. Pada penelitian ini menggunakan teknik analisis deskriptif kualitatif, yaitu suatu metode penelitian yang bersifat menggambarkan kenyataan atau fakta sesuai dengan data yang diperoleh dengan tujuan untuk mengetahui prestasi belajar yang dicapai siswa juga untuk memperoleh respon siswa terhadap kegiatan pembelajaran serta aktivitas siswa selama proses pembelajaran.

Untuk menganalisis tingkat keberhasilan siswa setelah proses belajar mengajar setiap siklus dilakukan dengan cara memberikan evaluasi berupa soal tes tertulis pada setiap akhir siklus. Diman hasil analisis dihitung dengan menggunakan statistik sederhana

\section{HASIL DAN PEMBAHASAN}

Data penelitian yang diperoleh berupa hasil uji coba item butir soal, data observasi berupa pengamatan pengelolaan belajar aktif dan pengamatan aktivitas siswa dan guru pada akhir pembelajaran, dan data tes formatif siswa pada setiap siklus.

Data hasil uji coba item butir soal digunakan untuk mendapatkan tes yang betulbetul mewakili apa yang diinginkan. Data ini selanjutnya dianalisis tingkat validitas, reliabilitas, taraf kesukaran, dan daya pembeda.

Data tes formatif untuk mengetahui peningkatan prestasi belajar siswa setelah diterapkan gabungan metode ceramah dengan metode belajar aktif model pengajaran autentik.

\section{Siklus I}

\section{Tahap Perencanaan}

Pada tahap ini peneliti mempersiapkan perangkat pembelajaran yang terdiri dari rencana pelajaran 1, LKS 1 , soal tes formatif 1 dan alat-alat pengajaran yang mendukung.

\section{Tahap Kegiatan dan Pelaksanaan}

Pelaksanaan kegiatan belajar mengajar untuk siklus I dilaksanakan pada tanggal 12 September 2016 dengan jumlah 34 siswa. Dalam hal ini peneliti bertindak sebagai guru. Adapun proses belajar mengajar mengacu pada rencana pelajaran yang telah dipersiapkan. Pengamatan (observasi) dilaksanakan bersamaan dengan pelaksaaan belajar mengajar.

Pada akhir proses belajar mengajar siswa diberi tes formatif 1 dengan tujuan untuk mengetahui tingkat keberhasilan siswa dalam proses belajar mengajar yang telah dilakukan. Adapun data hasil penelitian pada siklus I adalah sebagai berikut: 
Table 1

Distribusi Nilai Tes Siklus I

\begin{tabular}{|c|c|c|c|c|c|c|c|}
\hline \multirow{2}{*}{ No. Urut } & \multirow{2}{*}{ Skor } & \multicolumn{2}{|c|}{ Keterangan } & \multirow{2}{*}{ No. Urut } & \multirow{2}{*}{ Skor } & \multicolumn{2}{|c|}{ Keterangan } \\
\hline & & $\mathbf{T}$ & TT & & & $\mathbf{T}$ & TT \\
\hline 1 & 80 & $\sqrt{ }$ & & 18 & 60 & & $\sqrt{ }$ \\
\hline 2 & 60 & & $\sqrt{ }$ & 19 & 70 & $\sqrt{ }$ & \\
\hline 3 & 80 & $\sqrt{ }$ & & 20 & 70 & $\sqrt{ }$ & \\
\hline 4 & 60 & & $\sqrt{ }$ & 21 & 70 & $\sqrt{ }$ & \\
\hline 5 & 60 & & $\sqrt{ }$ & 22 & 80 & $\sqrt{ }$ & \\
\hline 6 & 80 & $\sqrt{ }$ & & 23 & 70 & $\sqrt{ }$ & \\
\hline 7 & 70 & $\sqrt{ }$ & & 24 & 80 & $\sqrt{ }$ & \\
\hline 8 & 60 & & $\sqrt{ }$ & 25 & 60 & & $\sqrt{ }$ \\
\hline 9 & 70 & $\sqrt{ }$ & & 26 & 40 & & $\sqrt{ }$ \\
\hline 10 & 80 & $\sqrt{ }$ & & 27 & 70 & $\sqrt{ }$ & \\
\hline 11 & 90 & $\sqrt{ }$ & & 28 & 80 & $\sqrt{ }$ & \\
\hline 12 & 50 & & $\sqrt{ }$ & 29 & 90 & $\sqrt{ }$ & \\
\hline 13 & 70 & $\sqrt{ }$ & & 30 & 80 & $\sqrt{ }$ & \\
\hline 14 & 80 & $\sqrt{ }$ & & 31 & 60 & & $\sqrt{ }$ \\
\hline 15 & 60 & & $\sqrt{ }$ & 32 & 70 & $\sqrt{ }$ & \\
\hline 16 & 80 & $\sqrt{ }$ & & 33 & 70 & $\sqrt{ }$ & \\
\hline 17 & 60 & & $\sqrt{ }$ & 34 & 70 & $\sqrt{ }$ & \\
\hline Jumlah & 1190 & 10 & 7 & Jumlah & 1190 & 13 & 4 \\
\hline
\end{tabular}

Jumlah Skor Tercapai 2380

Jumlah Skor Maksimal Ideal 3400

Rata-Rata Skor Tercapai 70,00

\begin{tabular}{lll}
\hline Keterangan: & T & : Tuntas \\
& TT & $:$ Tidak Tuntas \\
& Jumlah siswa yang tuntas & $: 23$ \\
Jumlah siswa yang belum tuntas & $: 11$ \\
Klasikal & $:$ Belum tuntas
\end{tabular}

Tabel 2

Rekapitulasi Hasil Tes Pada Siklus I

\begin{tabular}{clc}
\hline No & \multicolumn{1}{c}{ Uraian } & Hasil Siklus I \\
\hline 1 & Nilai rata-rata tes formatif & 70,00 \\
2 & Jumlah siswa yang tuntas belajar & 23 \\
3 & Persentase ketuntasan belajar & 67,65 \\
\hline
\end{tabular}

Dari tabel di atas dapat dijelaskan bahwa dengan menerapkan gabungan metode ceramah dengan metode belajar aktif model pengajaran autentik diperoleh nilai rata-rata prestasi belajar siswa adalah 70,00 dan ketuntasan belajar

mencapai $70,00 \%$ atau ada 23 siswa dari 34 siswa sudah tuntas belajar. Hasil tersebut menunjukkan bahwa pada siklus pertama secara klasikal siswa belum tuntas belajar, karena siswa yang memperoleh nilai $\geq 65$ 
hanya sebesar $67,65 \%$ lebih kecil dari persentase ketuntasan yang dikehendaki yaitu sebesar $85 \%$. Hal ini disebabkan karena siswa masih merasa baru dan belum mengerti apa yang dimaksudkan dan digunakan guru dengan menerapkan gabungan metode ceramah dengan metode belajar aktif model pengajaran autentik.

\section{Refleksi}

Dalam pelaksanaan kegiatan belajar mengajar diperoleh informasi dari hasil pengamatan sebagai berikut: (1) Guru kurang baik dalam memotivasi siswa dan dalam menyampaikan tujuan pembelajaran. 2) Guru kurang baik dalam pengelolaan waktu. 3) Siswa kurang begitu antusias selama pembelajaran berlangsung.

\section{Refisi}

Pelaksanaan kegiatan belajar mengajar pada siklus I ini masih terdapat kekurangan, sehingga perlu adanya refisi untuk dilakukan pada siklus berikutnya; (1) Guru perlu lebih terampil dalam memotivasi siswa dan lebih jelas dalam menyampaikan tujuan pembelajaran. Dimana siswa diajak untuk terlibat langsung dalam setiap kegiatan yang akan dilakukan. (2) Guru perlu mendistribusikan waktu secara baik dengan menambahkan informasi-informasi yang dirasa perlu dan memberi catatan. (3) Guru harus lebih terampil dan bersemangat dalam memotivasi siswa sehingga siswa bisa lebih antusias.

\section{Siklus II}

\section{Tahap Perencanaan}

Pada tahap ini peneliti mempersiapkan perangkat pembelajaran yang terdiri dari rencana pelajaran 2 , LKS, 2, soal tes formatif 2 dan alat-alat pengajaran yang mendukung.

\section{Tahap Kegiatan Dan Pelaksanaan}

Pelaksanaan kegiatan belajar mengajar untuk siklus II dilaksanakan pada tanggal 28 September 2016 dengan jumlah siswa 34 orang. Dalam hal ini peneliti bertindak sebagai guru. Adapun proses belajar mengajar mengacu pada rencana pelajaran dengan memperhatikan revisi pada siklus I, sehingga kesalahan atau kekurangan pada siklus I tidak terulang lagi pada siklus II. Pengamatan (observasi) dilaksanakan bersamaan dengan pelaksanaan belajar mengajar.

Pada akhir proses belajar mengajar siswa diberi tes formatif II dengan tujuan untuk mengetahui tingkat keberhasilan siswa dalam proses belajar mengajar yang telah dilakukan. Instrumen yang digunakan adalah tes formatif II. Adapun data hasil penelitian pada siklus II adalah sebagai berikut.

Table 3

Distribusi Nilai Tes Siklus II

\begin{tabular}{|c|c|c|c|c|c|c|c|}
\hline \multirow{2}{*}{ No. Urut } & \multirow{2}{*}{ Skor } & \multicolumn{2}{|c|}{ Keterangan } & \multirow{2}{*}{ No. Urut } & \multirow{2}{*}{ Skor } & \multicolumn{2}{|c|}{ Keterangan } \\
\hline & & $\mathbf{T}$ & TT & & & $\mathbf{T}$ & TT \\
\hline 1 & 80 & $\sqrt{ }$ & & 18 & 70 & $\sqrt{ }$ & \\
\hline 2 & 70 & $\sqrt{ }$ & & 19 & 60 & & $\sqrt{ }$ \\
\hline 3 & 90 & $\sqrt{ }$ & & 20 & 90 & $\sqrt{ }$ & \\
\hline 4 & 60 & & $\sqrt{ }$ & 21 & 90 & $\sqrt{ }$ & \\
\hline 5 & 70 & $\sqrt{ }$ & & 22 & 80 & $\sqrt{ }$ & \\
\hline 6 & 60 & & $\sqrt{ }$ & 23 & 80 & $\sqrt{ }$ & \\
\hline 7 & 70 & $\sqrt{ }$ & & 24 & 80 & $\sqrt{ }$ & \\
\hline 8 & 80 & $\sqrt{ }$ & & 25 & 60 & & $\sqrt{ }$ \\
\hline 9 & 60 & & $\sqrt{ }$ & 26 & 70 & $\sqrt{ }$ & \\
\hline 10 & 70 & $\sqrt{ }$ & & 27 & 80 & $\sqrt{ }$ & \\
\hline
\end{tabular}




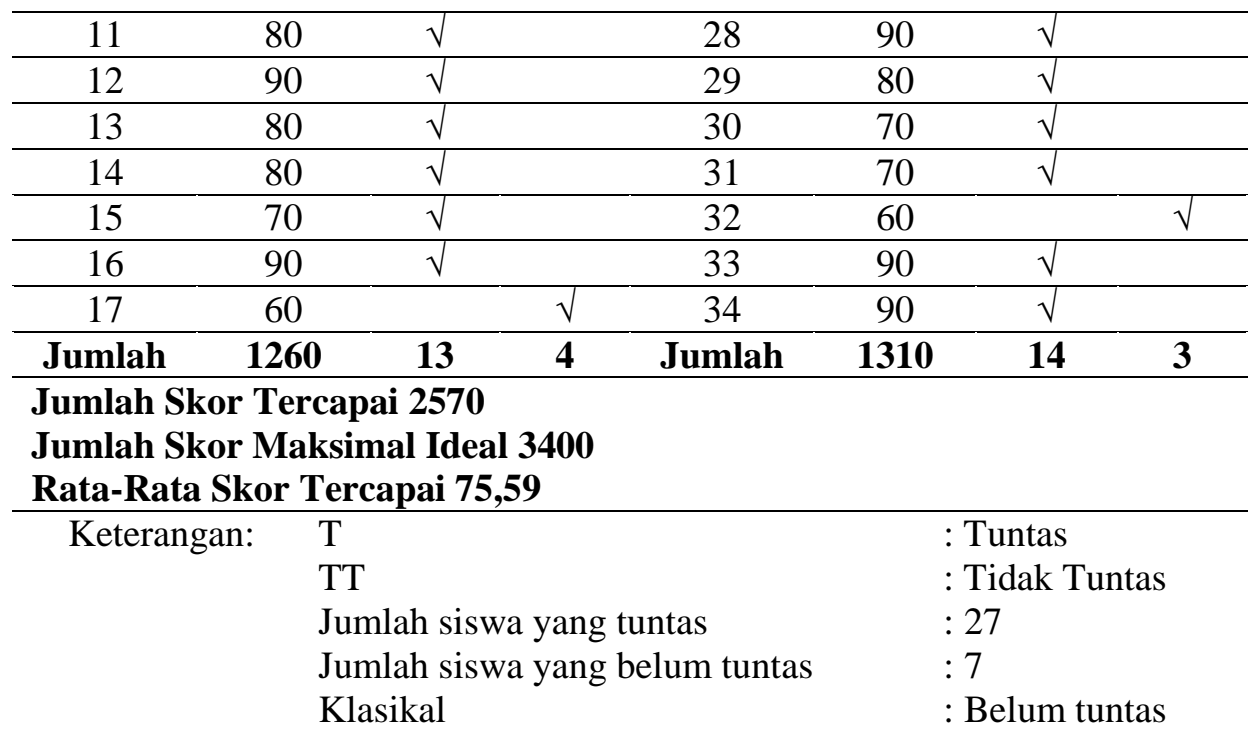

Tabel 4

Rekapitulasi Hasil Tes Pada Siklus II

\begin{tabular}{clcl}
\hline No & \multicolumn{1}{c}{ Uraian } & Hasil Siklus II \\
\hline 1 & Nilai rata-rata tes formatif & 75,59 \\
2 & Jumlah siswa yang tuntas belajar & 27 \\
3 & Persentase ketuntasan belajar & 79,41 & \\
\hline di atas diperoleh nilai rata-rata & kesimpulan/menemukan & konsep. & (3)
\end{tabular}

Dari tabel di atas diperoleh nilai rata-rata prestasi belajar siswa adalah 75,59 dan ketuntasan belajar mencapai $79,41 \%$ atau ada 27 siswa dari 34 siswa sudah tuntas belajar. Hasil ini menunjukkan bahwa pada siklus II ini ketuntasan belajar secara klasikal telah mengalami peningkatan sedikit lebih baik dari siklus I. Adanya peningkatan hasil belajar siswa ini karena setelah guru menginformasikan bahwa setiap akhir pelajaran akan selalu diadakan tes sehingga pada pertemuan berikutnya siswa lebih termotivasi untuk belajar. Selain itu siswa juga sudah mulai mengerti apa yang dimaksudkan dan dinginkan guru dengan menerapkan gabungan metode ceramah dengan metode belajar aktif model pengajaran autentik.

\section{Refleksi}

Dalam pelaksanaan kegiatan belajar diperoleh informasi dari hasil pengamatan sebagai berikut: (1) Memotivasi siswa, (2) Membimbing siswa merumuskan
Pengelolaan waktu

\section{Revisi Rancangan}

Pelaksanaan kegiatan belajar pada siklus II ini masih terdapat kekurangankekurangan. Maka perlu adanya revisi untuk dilaksanakan pada siklus II antara lain:1)Guru dalam memotivasi siswa hendaknya dapat membuat siswa lebih termotivasi selama proses belajar mengajar berlangsung.2)Guru harus lebih dekat dengan siswa sehingga tidak ada perasaan takut dalam diri siswa baik untuk mengemukakan pendapat atau bertanya. 3) Guru harus lebih sabar dalam membimbing siswa merumuskan kesimpulan/menemukan konsep. 4) Guru harus mendistribusikan waktu secara baik sehingga kegiatan pembelajaran dapat berjalan sesuai dengan yang diharapkan.5)guru sebaiknya menambah lebih banyak contoh soal dan memberi soal-soal latihan pada siswa untuk 
dikerjakan pada setiap kegiatan belajar mengajar.

\section{Siklus III}

\section{Tahap Perencanaan}

Pada tahap ini peneliti mempersiapkan perangkat pembelajaran yang terdiri dari rencana pelajaran 3 , LKS 3, soal tes formatif 3 dan alat-alat pengajaran yang mendukung.

\section{Tahap kegiatan dan pengamatan}

Pelaksanaan kegiatan belajar mengajar untuk siklus III dilaksanakan pada tanggal 25 Oktober 2016 dengan jumlah 34 siswa. Dalam hal ini peneliti bertindak sebagai guru. Adapun proses belajar mengajar mengacu pada rencana pelajaran dengan memperhatikan revisi pada siklus II, sehingga kesalahan atau kekurangan pada siklus II tidak terulang lagi pada siklus III. Pengamatan (observasi) dilaksanakan bersamaan dengan pelaksanaan belajar mengajar.

Pada akhir proses belajar mengajar siswa diberi tes formatif III dengan tujuan untuk mengetahui tingkat keberhasilan siswa dalam proses belajar mengajar yang telah dilakukan. Instrumen yang digunakan adalah tes formatif III. Adapun data hasil penelitian pada siklus III adalah sebagai berikut:

Tabel 5

Distribusi Nilai Tes Siklus III

\begin{tabular}{|c|c|c|c|c|c|c|c|}
\hline \multirow{2}{*}{ No. Urut } & \multirow{2}{*}{ Skor } & \multicolumn{2}{|c|}{ Keterangan } & \multirow{2}{*}{ No. Urut } & \multirow{2}{*}{ Skor } & \multicolumn{2}{|c|}{ Keterangan } \\
\hline & & $\mathbf{T}$ & TT & & & $\mathbf{T}$ & TT \\
\hline 1 & 80 & $\sqrt{ }$ & & 18 & 70 & $\sqrt{ }$ & \\
\hline 2 & 90 & $\sqrt{ }$ & & 19 & 80 & $\sqrt{ }$ & \\
\hline 3 & 90 & $\sqrt{ }$ & & 20 & 90 & $\sqrt{ }$ & \\
\hline 4 & 60 & & $\sqrt{ }$ & 21 & 90 & $\sqrt{ }$ & \\
\hline 5 & 90 & $\sqrt{ }$ & & 22 & 90 & $\sqrt{ }$ & \\
\hline 6 & 90 & $\sqrt{ }$ & & 23 & 80 & $\sqrt{ }$ & \\
\hline 7 & 90 & $\sqrt{ }$ & & 24 & 90 & $\sqrt{ }$ & \\
\hline 8 & 80 & $\sqrt{ }$ & & 25 & 80 & $\sqrt{ }$ & \\
\hline 9 & 80 & $\sqrt{ }$ & & 26 & 80 & $\sqrt{ }$ & \\
\hline 10 & 70 & $\sqrt{ }$ & & 27 & 80 & $\sqrt{ }$ & \\
\hline 11 & 90 & $\sqrt{ }$ & & 28 & 90 & $\sqrt{ }$ & \\
\hline 12 & 90 & $\sqrt{ }$ & & 29 & 80 & $\sqrt{ }$ & \\
\hline 13 & 60 & & $\sqrt{ }$ & 30 & 90 & $\sqrt{ }$ & \\
\hline 14 & 80 & $\sqrt{ }$ & & 31 & 70 & $\sqrt{ }$ & \\
\hline 15 & 90 & $\sqrt{ }$ & & 32 & 80 & $\sqrt{ }$ & \\
\hline 16 & 90 & $\sqrt{ }$ & & 33 & 90 & $\sqrt{ }$ & \\
\hline 17 & 60 & & $\sqrt{ }$ & 34 & 90 & $\sqrt{ }$ & \\
\hline Jumlah & 1380 & 14 & 3 & Jumlah & 1420 & 17 & - \\
\hline \multicolumn{8}{|c|}{$\begin{array}{l}\text { Jumlah Skor Tercapai } 2800 \\
\text { Jumlah Skor Maksimal Ideal } 3400 \\
\text { Rata-Rata Skor Tercapai 82,35 }\end{array}$} \\
\hline
\end{tabular}

Keterangan: $\mathrm{T}$

TT

Jumlah siswa yang tuntas

Jumlah siswa yang belum tuntas

Klasikal
: Tuntas

: Tidak Tuntas

$: 31$

$: 3$

: Tuntas 
Tabel 6

Rekapitulasi Hasil Tes Pada Siklus III

\begin{tabular}{clc}
\hline No & \multicolumn{1}{c}{ Uraian } & Hasil Siklus III \\
\hline 1 & Nilai rata-rata tes formatif & 82,35 \\
2 & Jumlah siswa yang tuntas belajar & 31 \\
3 & Persentase ketuntasan belajar & 91,17 \\
\hline
\end{tabular}

Berdasarkan tabel diatas diperoleh nilai rata-rata tes formatif sebesar 82,35 dan dari 34 siswa yang telah tuntas sebanyak 31 siswa dan 3 siswa belum mencapai ketuntasan belajar. Maka secara klasikal ketuntasan belajar yang telah tercapai sebesar $91,17 \%$ (termasuk kategori tuntas). Hasil pada siklus III ini mengalami peningkatan lebih baik dari siklus II. Adanya peningkatan hasil belajar pada siklus III ini dipengaruhi oleh adanya peningkatan kemampuan guru dalam menerapkan belajar aktif sehingga siswa menjadi lebih terbiasa dengan pembelajaran seperti ini sehingga siswa lebih mudah dalam memahami materi yang telah diberikan.

\section{Refleksi}

Pada tahap ini akan dikaji apa yang telah terlaksana dengan baik maupun yang masih kurang baik dalam proses belajar mengajar dengan penerapan gabungan metode ceramah dengan metode belajar aktif model pengajaran autentik. Dari datadata yang telah diperoleh dapat diuraikan sebagai berikut: (1) Selama proses belajar mengajar guru telah melaksanakan semua pembelajaran dengan baik. Meskipun ada beberapa aspek yang belum sempurna, tetapi persentase pelaksanaannya untuk setiap aspek cukup besar. (2) Berdasarkan data hasil pengamatan diketahui bahwa siswa aktif selama proses belajar berlangsung. (3) Kekurangan pada siklussiklus sebelumnya sudah mengalami perbaikan dan peningkatan sehingga menjadi lebih baik. (4) Hasil belajar siswa pada siklus III mencapai ketuntasan.

\section{Revisi Pelaksanaan}

Pada siklus III guru telah menerapkan belajar aktif dengan baik dan dilihat dari aktivitas siswa serta hasil belajar siswa pelaksanaan proses belajar mengajar sudah berjalan dengan baik. Maka tidak diperlukan revisi terlalu banyak, tetapi yang perlu diperhatikan untuk tindakah selanjutnya adalah memaksimalkan dan mempertahankan apa yang telah ada dengan tujuan agar pada pelaksanaan proses belajar mengajar selanjutnya penerapan gabungan metode ceramah dengan metode belajar aktif model pengajaran autentik dapat meningkatkan proses belajar mengajar sehingga tujuan pembelajaran dapat tercapai.

\section{Ketuntasan Hasil belajar Siswa}

Melalui hasil peneilitian ini menunjukkan bahwa gabungan metode ceramah dengan metode belajar aktif model pengajaran autentik memiliki dampak positif dalam meningkatkan prestasi belajar siswa. Hal ini dapat dilihat dari semakin mantapnya pemahaman siswa terhadap materi yang disampaikan guru (ketuntasan belajar meningkat dari siklus I, II, dan III) yaitu masing-masing $67,65 \%, 79,41 \%$, dan 91,17\%. Pada siklus III ketuntasan belajar siswa secara klasikal telah tercapai.

\section{Kemampuan Guru dalam Mengelola Pembelajaran}

Berdasarkan analisis data, diperoleh aktivitas siswa dalam proses pembelajaran dalam setiap siklus mengalami peningkatan. Hal ini berdampak positif terhadap prestasi belajar siswa yaitu dapat ditunjukkan dengan meningkatnya nilai rata-rata siswa 
pada setiap siklus yang terus mengalami peningkatan.

\section{Aktivitas Guru dan Siswa Dalam Pembelajaran}

Berdasarkan analisis data, diperoleh aktivitas siswa dalam proses pembelajaran Pengetahuan Sosial pada pokok bahasan wawasan nusantara dengan gabungan metode ceramah dengan metode belajar aktif model pengajaran autentik yang paling dominan adalah mendengarkan/ memperhatikan penjelasan guru, dan diskusi antar siswa/antara siswa dengan guru. Jadi dapat dikatakan bahwa aktivitas siswa dapat dikategorikan aktif.

Sedangkan untuk aktivitas guru selama pembelajaran telah melaksanakan langkahlangkah belajar aktif dengan baik. Hal ini terlihat dari aktivitas guru yang muncul di antaranya aktivitas membimbing dan mengamati siswa dalam mengerjakan kegiatan LKS / menemukan konsep, menjelaskan, memberi umpan balik/evaluasi/tanya jawab dimana prosentase untuk aktivitas di atas cukup besar.

\section{SIMPULAN DAN SARAN}

\section{Simpulan}

Dari hasil kegiatan pembelajaran yang telah dilakukan selama tiga siklus, dan berdasarkan seluruh pembahasan serta analisis yang telah dilakukan dapat disimpulkan sebagai berikut: (1) Pembelajaran dengan gabungan metode ceramah dengan metode belajar aktif model pengajaran autentik memiliki dampak positif dalam meningkatkan prestasi belajar siswa yang ditandai dengan peningkatan ketuntasan belajar siswa dalam setiap siklus, yaitu siklus I $(67,65 \%)$, siklus II $(79,41 \%)$, siklus III $(91,17 \%)$. (2) Penerapan gabungan metode ceramah dengan metode belajar aktif model pengajaran autentik mempunyai pengaruh positif, yaitu dapat meningkatkan motivasi belajar siswa yang ditunjukan dengan rata-rata jawaban siswa hasil wawancara yang menyatakan bahwa siswa tertarik dan berminat dengan gabungan metode ceramah dengan metode belajar aktif model pengajaran autentik sehingga mereka menjadi termotivasi untuk belajar.

Saran

Dari hasil penelitian yang diperoleh dari uraian sebelumnya agar proses belajar mengajar Ilmu Pengetahuan Sosial lebih efektif dan lebih memberikan hasil yang optimal bagi siswa, maka disampaikan saran sebagai berikut (1). Untuk melaksanakan belajar aktif memerlukan persiapan yang cukup matang, sehingga guru harus mampu menentukan atau memilih topik yang benarbenar bisa diterapkan dengan gabungan metode ceramah dengan metode belajar aktif model pengajaran autentik dalam proses belajar mengajar sehingga diperoleh hasil yang optimal. (2) Dalam rangka meningkatkan prestasi belajar siswa, guru hendaknya lebih sering melatih siswa dengan metode pengajaran yang berbeda, walau dalam taraf yang sederhana, dimana siswa nantinya dapat menemukan pengetahuan baru, memperoleh konsep dan keterampilan, sehingga siswa berhasil atau mampu memecahkan masalah-masalah yang dihadapinya. (3) Untuk penelitian yang serupa hendaknya dilakukan perbaikanperbaikan agar diperoleh hasil yang lebih baik.

\section{DAFTAR RUJUKAN}

Ali, Muhammad. 1996. Guru Dalam Proses Belajar Mengajar. Bandung: Sinar Baru Algesindon.

Arikunto, Suharsimi. 1993. Manajemen Mengajar Secara Manusiawi. Jakarta: Rineksa Cipta. 
Arikunto, Suharsimi. 2001. Dasar-Dasar Evaluasi Pendidikan. Jakarta: Bumi Aksara.

Arikunto, Suharsimi. 1999. Prosedur Penelitian Suatu Pendekatan Praktek. Jakarta: Rineksa Cipta.

Combs. Arthur. W. 1984. The Profesional Education of Teachers. Allin and Bacon, Inc. Boston.

Djamarah, Syaiful Bahri. 2002. Strategi Belajar Mengajar. Jakarta: Rineksa Cipta.

Djamarah. Syaiful Bahri. 2002. Psikologi Belajar. Jakarta: Rineksa Cipta.

Foster, Bob. 1999. Seribu Pena SLTP Kelas I. Jakarta: Erlangga.

Hadi, Sutrisno. 1981. Metodogi Research. Yayasan Penerbitan Fakultas Psikologi Universitas Gajah Mada. Yoyakarta.

Hasibuan. J.J. dan Moerdjiono. 1998. Proses Belajar Mengajar. Bandung: Remaja Rosdakarya.

Margono. 1997. Metodologi Penelitian Pendidikan. Jakarta. Rineksa Cipta.

Melvin, L. Seiberman. 2000. Active Learning. Bandung: Nuansa dan Nusamedia

Mukhlis, Abdul. (Ed). 2000. Penelitian Tindakan Kelas. Makalah PanitianPelatihan Penulisan Karya Ilmiah untuk Guru-guru se-Kabupaten Tuban.
Mursell, James ( - ). Succesfull Teaching (terjemahan). Bandung: Jemmars.

Ngalim, Purwanto M. 1990. Psikologi Pendidikan. Bandung: PT. Remaja Rosdakarya.

Nur, Moh. 2001. Pemotivasian Siswa untuk Belajar. Surabaya. University Press. Universitas Negeri Surabaya.

Poerwodarminto. 1991. Kamus Umum Bahasa Indonesia. Jakarta: Bina Ilmu.

Rustiyah, N.K. 1991. Strategi Belajar Mengajar. Jakarta: Bina Aksara.

Sardiman, A.M. 1996. Interaksi dan Motivasi Belajar Mengajar. Jakarta: Bina Aksara.

Soekamto, Toeti. 1997. Teori Belajar dan Model Pembelajaran. Jakarta: PAUPPAI, Universitas Terbuka.

Suryosubroto, b. 1997. Proses Belajar Mengajar di Sekolah. Jakarta: PT. Rineksa Cipta.

Syah, Muhibbin. 1995. Psikologi Pendidikan, Suatu Pendekatan Baru. Bandung: Remaja Rosdakarya.

Usman, Moh. Uzer. 2001. Menjadi Guru Profesional. Bandung: Remaja Rosdakarya.

Wetherington. H.C. and W.H. Walt. Burton. 1986. Teknik-teknik Belajar dan Mengajar. (terjemahan) Bandung: Jemmars. 